\title{
Myotonic Dystrophy Type 1 Diagnostics: A Changing Trend
}

\author{
Kunal Singh \\ (Manipal Life Sciences Centre,Manipal University,India)
}

\begin{abstract}
Myotonic dystrophy type 1 or Steinert's disease is the most common form of adult muscular dystrophy affecting multiple systems with a wide spectrum of phenotypes. This paper focuses on the different methods to diagnose myotonic dystrophy type 1 that have been used over the years and the various modifications that have been made to the previous diagnostics. The different diagnostic assays and their different advantages and disadvantages are discussed.
\end{abstract}

Keywords: Myotonic Dystrophy Type 1, Diagnostics, Method

\section{Introduction}

1.1. Prevalence:Myotonic dystrophy or dystrophia myotonica (DM) is a group of disorders affecting multiple systems with a wide spectrum of phenotypes. It is an autosomal dominant condition which may be congenital or adult in onset. Myotonic dystrophy type 1 (DM1) or Steinert's disease is the most common form of muscular dystrophy in adults, with a prevalence of 1 in every 8,000 individual worldwide[1].However, DM1 is less prevalent in certain areas of Japan $(1: 100,000)$, Asia $(1: 18,000)$, and Iceland $(1: 10,000)$, and even rarer among African blacks [2].

1.2.Gene Location:In case of DM1, the defect in the gene is localized to the long arm of chromosome 19 from 19q13.2-13.3 encoding a protein kinase known as myotonin protein kinase coded by the myotonic dystrophy protein kinase (DMPK) gene. $D M P K$ is the only gene found to be associated with DM1[3][4]. The trinucleotide repeat is located in the 3' untranslated region of $D M P K$ gene and has an altered number of CTG trinucleotide repeat. The severity of the disorder being directly correlated to the number of repeats [2][5].

1.3.Mechanism:The number of CTG repeat is highly polymorphic in both normal and affected individuals. A normal individual possesses alleles with the number of CTG repeats ranging between 5 and 35 , whereas an affected individual showing clinical signs of myotonic dystrophy has CTG repeats varying from 50 to several thousand in number. The alleles which fall in the range of 36 to 49 CTG repeats are without any known clinical symptoms and are hence considered as 'Premutations' having the potential to expand during gametogenesis. As can be seen in Table 1, more the number of CTG repeats in affected individuals more severe is the disorder. The stability of transfer of the repeat is also affected causing a larger number of repeats being transferred to the offsprings[5][6][7][8].Thus as the number of CTG repeat units increases in the DMPK gene, it also causes an earlier onset of the disorder in the later generations within a family. This is known as 'Anticipation' thus linking the phenotypic severity of the disease with the age at which it occurs in a particular individual[9].

\subsection{Classification}

Table1: Classification based on number of repeats

\begin{tabular}{|c|l|l|}
\hline CTG repeats & \multicolumn{1}{|c|}{ Phenotypic severity } & \multicolumn{1}{|c|}{ Stability } \\
\hline $\mathbf{5 - 3 5}$ & $\begin{array}{l}\text { Normal individuals with no phenotypic } \\
\text { features }\end{array}$ & The repeats are Stable \\
\hline $\mathbf{3 6 - 4 9}$ & Permutations showing no phenotypic features & They may or may not be stable \\
\hline $\mathbf{5 0 - 1 5 0}$ & $\begin{array}{l}\text { In lower number may not show any } \\
\text { phenotypic features or may show features of } \\
\text { mild or classic DM1 }\end{array}$ & These are unstable \\
\hline Over 150 & $\begin{array}{l}\text { Shows high phenotypic features of classical, } \\
\text { congenital or juvenile DM1 }\end{array}$ & These are unstable \\
\hline
\end{tabular}

The classification of DM1 can be done clinically into four different types:

1.4.1. Mild DM1: This type of myotonic dystrophy is composed of mildly affected individuals who and may present with premature cataracts as the sole clinical features. There is a chance of myopathy and abnormalities in cardiac conduction which may have a late onset. The myotonia in this case can be detected by electromyography. 
1.4.2. Classic DM1: It is also known as 'Adult onset' DM1 that may occur in the twenty's or thirty's of an individual's life with weakening of distal bones being the most common symptom involving the flexors of the arms and legs (fingers) affecting the grasping capability of the hands and balance of the body. In addition, a patient may also present with the conditions which occur in the case of Mild DM1. They may also suffer from gastrointestinal symptoms like abdominal pain, diarrhea, constipation etc and fatigue affecting the quality of life of an individual.

1.4.3. Juvenile DM1: It is similar to the mild and classic forms of DM1 mentioned above in the phenotypic features, but in this case which is a more severe form as compared to the other two an affected individual may also suffer from behavioural and cognitive abnormalities and may have difficulty when it comes to either learning in school or when it comes to socializing.

1.4.4. Congenital DM1: One of the symptoms in this case may be seen as early as when fetal development is monitored in the form of an excess amniotic fluid being present in the developing fetus and poor fetal movement which can be seen before the birth of an infant with congenital DM1 of an affected mother. The infant presents with severe respiratory disorder, a weak facial and jaw muscle and hence having feeding and suckling difficulty. The infants may also present with clubbed feat, muscle contractions and a delay in attaining the developmental milestones with mental retardation being very common. There is a very high infant mortality rate. The absence of myotonia makes it difficult to detect even via electromyography. It does not present any similarities with the muscle biopsies found in classical DM1 thus a confirmation can only be made by DNA analysis[1][6].

\section{Molecular Diagnosis of Myotonic Dystrophy type 1}

The molecular diagnosis of DM1 is a definitive way to confirm the number of CTG repeats, it is a more potent way to confirm the clinical diagnosis. The method of molecular diagnosis is very diverse and attempts have been made over the years to make the method of molecular diagnosis more efficient and effective hence a lot of modification to the original method exists. A brief overview of some of the methods has been discussed below

2.1. Southern Blot AnalysisThe method of southern blotting has been a very important diagnostic tool for the DM1 cases. It has undergone various modifications over the years in order to increase the detection efficiency. It is broadly divided into two types:

2.1.1. Southern Blotting of Genomic DNA:In this case, the genomic DNA is digested with appropriate restriction enzymes (BamHI, EcoRI, $N c o \mathrm{I}$ or $B g l \mathrm{I})$. This technique has proved to be of great importance for the detection of DMPK alleles of size of 100 CTG repeats and above [10]. Although the conventional method is useful in the detection of the large CTG repeats in the case of DM1 individuals but it becomes ineffective for small size CTG repeats. Moreover it is a very time consuming and a laborious process which requires a large amount of high molecular weight genomic DNA rendering it unsuitable for automation [11][12].

As shown in appendix, modifications have been done to increase the resolution and quality of the results with the use of field inversion gel electrophoresis (FIGE)[13] or pulse field gel electrophoresis (PFGE)[14]. Breaking the high molecular weight DNA into smaller pieces can be achieved by incubating the gel in $\mathrm{HCl}$ before transferring to the nylon hence increasing the efficiency of transfer [12].

2.1.2. Southern Blotting of long range PCR products:This technique requires specific conditions to amplify large fragments with the appropriate normal and affected samples followed by the addition of an end labelled probe[15]. This process is similar to Triplet Primed-PCR in the case that duplicated or deleted repeats in a sequence may remain undetectable. In this case the expanded repeats will appear as smears or multiple fragments [16].

2.2. PCR based Diagnostics:Since its advent as a tool for molecular diagnosis a constant effort has been made to improve the efficacy of this method and hence several modifications of it exist. An attempt has been made to summarize the various PCR methods that have been used over the years with the various concentrations and the altered conditions used while doing the modifications and compiled as shown in appendix.

2.2.1. Conventional PCR: This is a very simple and fast process that can be used to detect of smaller expansions in milder cases of DM1 individuals with CTG repeats below 100 which is very difficult to detect via Southern Blotting however it fails to detect larger repeats and is not preferred for direct diagnosis. Thus it is used generally in the detection of repeats pertaining to normal individuals and small expansions. But a very distinct advantage of this process is that the detection range can be extended to cover a slightly larger number of 
CTG repeats by using special additives which can be seen in appendix [2][17][18]. In another way the CTG repeats can also be detected and characterized rapidly by the use of primers which are fluorescently labelled and made to flank the CTG-repeat region and the analysis of the PCR product can be done by capillary electrophoresis [16] [19].

2.2.2. Small Pool (SP) PCR: This PCR technique is used less frequently and is used with Southern Blot Analysis to give smeared or diffused bands by the amplification of restriction digested and diluted genomic product. With the aid of auto-radiography and oligo specific hybridization techniques it can detect a CTG repeat size of up to 1300 . This makes it a very lengthy process which being time consuming when it comes to analysis $[20][21] .$.

2.2.3. Long range PCR: Long range PCR assays have been found to improve the amplification of the PCR products. They give a higher resolution in sizing of CTG repeats as compared to the conventional PCR being in the range of 800-1700 CTG repeats after direct visualization on gels, this can be further increased to 2700-3700 CTG after transferring to nylon membrane or using oligo specific probe. Thus Long range PCR is coupled with Southern Blot Analysis to give better resolution. This is a simple and rapid process with an effective range that can be increased just like in the case of conventional PCR by the use of special additives. To add to the various sets of primer combinations which flank the repeat regions they also make use of various modifications of the reagents which include special DNA polymerases, glycerol, PCR buffers, Taq stabilizers, GC-enhancers, dimethyl sulfoxide (DMSO) and 7-deaza GTP in case of dGTP are some of the modifications which are listed out in the appendix[22][23][24][25].

Different names have been given to PCR on the basis of their functional modification of the conventional types like Hot Start PCR, which follows a modified procedure from a conventional PCR of manually heating the reaction mixture before adding polymerase. This is done to prevent the nonspecific amplification that takes place at lower temperature[24], Heat Pulse Extension (HPE) PCR is another PCR which is done to increase the amplification efficiency over repetitive and GC rich sequences [26] or Nested PCR which is another modified form of PCR which is done to reduce non-specific binding and uses two sets of primers and PCR product of the first reaction being the template for the second reaction [27].

2.2.4. Triplet-repeat Primed (TP) PCR: As the name suggests, it is a PCR which makes use of three primers in which one lies outside the CTG repeat and one within the repeat known as the 'triplet primed primer' which is added in limiting amount in comparison to the other primer and a primer known as the 'tail primer' which has a sequence complementary to the 'triplet primed primer' and is labelled with a fluorescent dye [28]. The result that is generated by a TP-PCR is a mixture of PCR fragments of different sizes and hence gives a smear on the gel and capillary electrophoresis has been found to be a useful tool for analysis. This is a very useful tool as a wide range of expansions can be detected but due to the signal going off in higher sizes hence it is not a reliable tool for knowing the length information. TP-PCR also fails to detect expansions in the presence of rare interruptions thus in order to exclude a false negative result a bidirectional TP-PCR Southern Blotting is used [29][30][31].

The method of analysis in case of TP-PCR has been modified over the years to make it simpler, reproducible with the reliability of the results. The coupling of it with capillary electrophoresis has made it easier to attain the exact number of CTG repeats by counting the number of peaks. In addition to the methodological advantages of this making fast generation of the results capillary electrophoresis makes the process almost completely automatic and reduces the time of requirement from a week in case of Southern Blot Analysis to as less as three hours in case of TP-PCR which can be a crucial time when it comes to prenatal diagnosis[11].

2.2.5. Quantitative fluorescent (QF) PCR:Quantitative fluorescent (QF) PCR is one of the most recent recruits in the diagnosis of DM1. Having a close association with multiplex PCR it uses three sets of primer each flanking to the either side of the region of interest of $D M P K$ gene and to the gene of interest and the reaction is performed together for the three sets in one multiplex reaction with one primer from each of the three sets of primers being fluorescently labelled with the same fluorescent tag for detection. The method though very useful is generally used in the detection of the CTG repeats below 100 and in order to increase the effective range another step needs to be added. This is a useful technique to know the zygosity of the allele to know if the allele is homozygous or heterozygous in nature hence better diagnosis. The selected markers used for reference should not contain deletions or duplications [25][32]. This is a particularly useful technique in case of preimplantation genetic diagnosis (PGD) for DM as it applies the use of polymorphic markers like D19S112 and APOC2 [24] or 
APOC2 and D21S1414 which are made to amplify with the DMPK gene thus providing in diagnosis and hence allowing contaminants to be detected which are a serious problem [33].

2.3. In situ Hybridization Technique:This is a type of hybridization technique which makes use of labelled probes in order to detect a particular target sequence. It is particularly useful technique for the detection of CTG repeat size of over 100 but is a time consuming process that requires highly skilled labour. Long PCR is a very useful technique but has limitations in interpreting results in the case of somatic mosaicism and in cases where the expansion size exceeds the PCR amplification range. To overcome these problems RNA fluorescence in situ hybridization (RNA-FISH) has been found to be very useful. It is used to detect the presence or absence of nuclear foci of the expanded trinucleotide repeat in the interphase nuclei of the trophoblastic cells in suspected DM1 fetuses [34][35].

Table 2: Summarization of the advantages and disadvantages of various techniques

\begin{tabular}{|c|c|c|c|c|c|}
\hline $\begin{array}{l}\text { S.No } \\
\text {. }\end{array}$ & Technique & Modification & Advantages & Disadvantages & References \\
\hline \multirow[t]{5}{*}{1.} & \multirow[t]{5}{*}{$\begin{array}{l}\text { Polymerase } \\
\text { Chain Reaction } \\
\text { (PCR) }\end{array}$} & Coventional & $\begin{array}{l}\text {-Simple \& fast } \\
\text {-Detects small CTG } \\
\text { repeats which are not } \\
\text { detectable by SBA } \\
\text {-Effective range can be } \\
\text { increased by the addition of } \\
\text { special additives }\end{array}$ & $\begin{array}{l}\text {-Can only detect small } \\
\text { sized repeats. } \\
\text {-Effective for CTG below } \\
100 \text { repeats. }\end{array}$ & $\begin{array}{l}\text { Brunner et al., 1992; } \\
\text { Kim et al., 2008; } \\
\text { Prior, 2009; } \\
\text { Bachinski } \text { et al., 2009; } \\
\text { Kamsteeg et al., } 2012\end{array}$ \\
\hline & & Small Pool & $\begin{array}{l}\text {-Resolves discrete bands } \\
\text { when used with SBA } \\
\text {-Effective range can be } \\
\text { extended to } 1300 \mathrm{CTG} \\
\text { repeats }\end{array}$ & $\begin{array}{l}\text {-Laborious \& time } \\
\text { consuming } \\
\text {-Visualization of larger } \\
\text { repeats requires an } \\
\text { association with SBA and } \\
\text { hybrisation techniques }\end{array}$ & $\begin{array}{l}\text { Monckton et al.,1995; } \\
\text { Wong et al., } 1995\end{array}$ \\
\hline & & Long range & $\begin{array}{l}\text {-Simple \& fast } \\
\text {-Effective range between } \\
800-1700 \text { CTG repeats } \\
\text { - Effective range can be } \\
\text { increased by the addition of } \\
\text { special additives and to } \\
\text { around } 3700 \text { CTG repeats } \\
\text { using hybridization } \\
\text { technique }\end{array}$ & $\begin{array}{l}\text { Attaining higher } \\
\text { resolution by } \\
\text { hybridization techniques } \\
\text { makes the process lengthy } \\
\text { and time consuming }\end{array}$ & $\begin{array}{l}\text { Cheng et al., 1996; } \\
\text { Brugnoni et al., 1997; } \\
\text { Kakorou et al., 2007; } \\
\text { Skrzypczak-Zeilinska et al., } \\
2009 ; \\
\text { Orpana et al., } 2012\end{array}$ \\
\hline & & $\begin{array}{l}\text { Triplet repeat } \\
\text { primed }\end{array}$ & $\begin{array}{l}\text {-New modifications have } \\
\text { made it reliable } \\
\text {-Robust } \\
\text {-Fast \& Simple } \\
\text {-Sizing for the presence or } \\
\text { absence of alleles }\end{array}$ & $\begin{array}{l}\text {-Sensitive to sequence } \\
\text { deletion or duplication } \\
\text {-Confirmation is needed } \\
\text { hence followed by SBA or } \\
\text { done as a bidirectional } \\
\text { assay }\end{array}$ & $\begin{array}{l}\text { Falk et al., 2006; } \\
\text { Musova et al., 2009; } \\
\text { Braida et al., 2010; } \\
\text { Radvansky et al., } 2010\end{array}$ \\
\hline & & $\begin{array}{l}\text { Quantitative } \\
\text { fluorescent }\end{array}$ & $\begin{array}{l}\text { - Very useful method in } \\
\text { PGD for DM1 } \\
\text {-Detects the zygosity of the } \\
\text { allele } \\
\text {-Use polymorphic markers } \\
\text { to identify contaminats }\end{array}$ & $\begin{array}{l}\text {-Cannot be used to detect } \\
\text { extensions over } 100 \\
\text { repeats. } \\
\text {-Multiplex PCR for better } \\
\text { diagnostics }\end{array}$ & $\begin{array}{l}\text { Skrzypczak-Zeilinska et al., } \\
\text { 2009; } \\
\text { Piyamogkol et al., 2001; } \\
\text { Kakourou et al., 2007; } \\
\text { Radvansky et al., } 2010\end{array}$ \\
\hline \multirow[t]{3}{*}{2.} & \multirow[t]{3}{*}{$\begin{array}{l}\text { Southern Blot } \\
\text { Analysis (SBA) }\end{array}$} & $\begin{array}{l}\text { SBA of } \\
\text { Genomic } \\
\text { DNA }\end{array}$ & $\begin{array}{l}\text {-Detects expansion size of } \\
\text { over } 100 \text { CTG repeats }\end{array}$ & $\begin{array}{l}\text {-It is a laborious and a } \\
\text { time consuming process } \\
\text {-Not suitable for the } \\
\text { detection of small size } \\
\text { repeats } \\
\text {-Requires large amount of } \\
\text { high molecular weight } \\
\text { genomic DNA }\end{array}$ & $\begin{array}{l}\text { Falk et al., 2006; } \\
\text { Carson et al., } 2009\end{array}$ \\
\hline & & $\begin{array}{l}\text { FIGE, PFGE } \\
\text { and gel } \\
\text { incubation in } \\
\mathrm{HCl} \text { prior to } \\
\text { transferring }\end{array}$ & $\begin{array}{l}\text { Increases quality and } \\
\text { resolution and increases the } \\
\text { efficiency of transfer of } \\
\text { genomic DNA }\end{array}$ & $\begin{array}{l}\text {-It is a time consuming } \\
\text { and laborious process }\end{array}$ & $\begin{array}{l}\text { Bachinski et al., 2003; } \\
\text { Jakubiczka et al., 2004; } \\
\text { Carson } \text { et al., } 2009\end{array}$ \\
\hline & & $\begin{array}{l}\text { SBA of Long } \\
\text { range PCR } \\
\text { product }\end{array}$ & $\begin{array}{l}\text { It increases the sensitivity } \\
\text { for the detection of large } \\
\text { CTG repeat }\end{array}$ & $\begin{array}{l}\text { - It is a time consuming } \\
\text { and laborious process } \\
\text {-It is very sensitive to } \\
\text { sequence deletion or } \\
\text { duplication. }\end{array}$ & $\begin{array}{l}\text { Gennarelli et al., 1998; } \\
\text { Kamsteeg et al., } 2012\end{array}$ \\
\hline
\end{tabular}




\begin{tabular}{|l|l|l|l|l|l|}
\hline 3. & $\begin{array}{l}\text { In situ } \\
\text { hybridization }\end{array}$ & $\begin{array}{l}\text {-Identifies expansions at the } \\
\text { level of RNA. } \\
\text {-It detects sizes above } 100 \\
\text { CTG repeats }\end{array}$ & $\begin{array}{l}\text { - It is a laborious and a } \\
\text { time consuming process } \\
\text {-It gives no information } \\
\text { about the size of the } \\
\text { expansion }\end{array}$ & $\begin{array}{l}\text { Liquori } \text { et al., 2001; } \\
\text { Bonifazi } \text { et al., 2006 }\end{array}$ & \\
\hline
\end{tabular}

\section{Conclusion}

The aim of this paper is to present a wide range of diagnostics for myotonic dystrophy Type 1 diagnostics that has been used over the years. Thus various modifications exist to the conventional methods that were started initially. The improved techniques offer better and faster diagnostics covering a wider range of CTG repeats but also have their own drawbacks hence it is best that a particular assay should be selected as per the experiment requirements like knowing the affected allele, zygosity of the alleles, the size of the expanded repeats that needs to be detected or if the information about the number of repeats is required. As listed in Table 2 some of the conventional methods are particularly useful in case of detecting the lower CTG repeats that occur in case of normal patients or patients with mild DM1.

On the other hand some of the techniques are useful only in the detection of larger CTG repeats like Southern Blot Analysis, which is ineffective for shorter repeat lengths. The other point that needs to be taken into consideration is the time taken to generate the result after successful analysis which can prove to be very important in case of prenatal diagnosis in which time can be a crucial factor. The time taken and the effort have been successfully reduced by the introduction of PCR based diagnostics. In order to make PCR based diagnostics more robust, reliable and accurate it is generally suggested to couple this diagnosis with another test to check for the accuracy. Thus in case of TP-PCR the diagnostic is generally done bidirectionally. The use of QF-PCR and Multiplex PCR has although made the PCR based diagnostics a little tedious but this has increased the accuracy of PCR based diagnosis as it identifies the presence or absence of expanded alleles apart from the sizing aspect and with the use of polymorphic markers it has made this method more reliable as it can identify any contaminants. The use of in situ hybridization technique is more or less secondary when the prior methods are not conclusive or if further validation is needed.

\section{References}

[1]. Harper PS, Myotonic Dystrophy (2nd ed. Philadelphia:W.B.Saunders,1989)

[2]. Prior TW, ACMG Standards and Guidelines:Technical standards and guidelines for myotonic dystrophy type 1 testing. Genetics in Medicine, 11, 2009, 552-555.

[3]. Brook JD, McCurrach ME, Harley HG, Buckler AJ, Church D, Aburatani H, Hunter K, Stanton VP, Thirion JP, Hudson T et al., Molecular basis of myotonic dystrophy expansion of a trinucleotide (CTG) repeat at the $3{ }^{\prime}$ end of a transcript encoding a protein kinase family member. Cell, 68, 1992, 799-808.

[4]. Mahadevan M, Tsilidifidis C, Sabourin L, Sabourin L, Shutler G, Amemiya C, Jansen G, Neville C, Narang M, Barcelo J et al., Myotonic dystrophy mutation: an unstable CTG repeat in the 3' untranslated region of the gene. Science, 255, 1992, $1253-1255$.

[5]. Hamshere MG, Harley H, Harper P, Brook JD and Brookfield JF Myotonic dystrophy: the correlation of (CTG) repeat length in leucocytes with age at onset is significantly only for patients with small expansions. Journal of Medical Genetics, 36, 1999, 59-61.

[6]. The International myotonic Dystrophy Consortium (IDMC) New nomenclature and DNA testing guidelines for myotonic dystrophy type 1(DM1). Neurology, 54, 2000, 1218-1221.

[7]. Lavedan C, Hofmann-Radvanyi H, Shelbourne P, Rabes JP, Duros C, Savoy D, Dehaupas I, Luce S, Johnson K and Junien C, Myotonic dystrophy: size and sex-dependent dynamics of CTG meiotic instability and somatic mosaicism. American Journal of Human Genetics, 52, 1993, 875-833.

[8]. Martorell L, Monckton DG, Sanchez A, Lopez De Munain A and Baiget M, Frequency and stability of the myotonic dystrophy type 1 premutation. Neurology, 56, 2001, 328-335.

[9]. Höweler CJ, Busch HF, Geraedts JP, Niermeijer MF and Staal A, Anticipation in myotonic dystrophy: fact or fiction? Brain: A Journal of Neurology, 112, 1989, 779-797.

[10]. Brook JD, McCurrach ME, Harley HG, Buckler AJ, Church D, Aburatani H, Hunter K, Stanton VP, Thirion JP, Hudson T et al., Molecular basis of myotonic dystrophy expansion of a trinucleotide (CTG) repeat at the $3^{\prime}$ end of a transcript encoding a protein kinase family member. Cell, 68, 1992, 799-808.

[11]. Falk M, Vojtísková M, Lukás Z, Kroupová I and Froster U, Simple procedure for automation detection of unstable alleles in the myotonic dystrophy and huntington's disease loci. Genetic Testing, 10, 2006, 85-97.

[12]. Carson NL, Analysis of repetitive regions in myotonic dystrophy type 1 and 2. Current Protocols in Human Genetics, Chapter 9 Unit 9.6,2006.

[13]. Bachinski LL, Udd B, Meola G, Sansone V, Bassez G, Eymard B, Thornton CA, Moxley RT, Harper PS, Rogers MT et al., Confirmation of the type 2 myotonic dystrophy (CCTG)n expansion mutation in patients with proximal myotonic myopathy/proximal myotonic dystrophy of different European origin: a single shared haplotype indicates an ancestral founder effect. American Journal of Human Genetics, 73, 2003, 835-848.

[14]. Jakubiczka S, Vielhaber S, Kress W, Küpferling P, Reuner U, Kunath B and Wieacker P Improvement of the diagnostic procedure in proximal myotonic myopathy/ myotonic dystrophy type 2. Neurogenetics, 5, 2004 55-59.

[15]. Gennarelli M, Pavoni M, Amicucci P, Novelli G and Dallapiccola B, A single polymerase chain reaction-based protocol for detecting normal and expanded alleles in myotonic dystrophy. Diagnostic Molecular Pathology, 7, 1998, $135-137$.

[16]. Kamsteeg EJ, Kress W, Catalli C, Hertz JM, Witsch-Baumgartner M, Buckley MF, van Engelen BG, Schwartz M and Scheffer H ,Best practice guidelines and recommendations on the molecular diagnosis of myotonic dystrophy types 1 and 2 . European Journal of Human Genetics, 20, 2012 1203-1208.

[17]. Brunner HG, Nillesen W, Van Oost BA, Jansen G, Wieringa B, Ropers HH and Smeets HJ, Presymptomatic diagnosis of myotonic dystrophy. Journal of Medical Genetics, 29, 1992, 780-784. 
[18]. Bachinski LL, Czernuszewicz T, Ramagli LS, Suominen T, Shriver MD, Udd B, Siciliano MJ and Krahe R, Premutation allele pool in myotonic dystrophy type 2. Neurology, 72, 2009,490-497.

[19]. Kim SY, Kim JY, Kim GP, Sung JJ, Lim KS, Lee KW, Chae JH, Hong YH, Seong MW and Park SS, Molecular and clinical characteristics of myotonic dystrophy type 1 in Koreans. The Korean Journal of Laboratory Medicine, 28, 2008, 483-492.

[20]. Monckton DG, Wong LJ, Ashizawa T and Caskey CT ,Somatic mosaicism, germline expansions, germline reversions and intergenerational reductions in myotonic dystrophy males: small pool PCR analyses. Human Molecular Genetics, 4, 1995,1-8.

[21]. Wong LC, Ashizawa T, Moncton DG, Caskey CT and Richards SC, Somatic heterogeneity of the CTG repeat in myotonic dystrophy is age and size dependent. American Journal of Human Genetics, 56, 1995, 114-122.

[22]. Cheng S, Barcelo JM and Krorneluk RG, Characterisation of large CTG repeat expansions in myotonic dystrophy alleles using PCR. Human Mutation, 7, 1996, 304-310.

[23]. Brugnoni R, Morandi L, Brambati B, Briscioli V, Cornelio F and Mantegazza R, A new non-radioactive method for the screening and prenatal diagnosis of myotonic dystrophy patients. Journal of Neurology, 245, 1998, 289-293.

[24]. Kakourou G, Dhanjal S, Daphnis D, Doshi A, Nuttall S, Gotts S, Serhal P, Delhanty J, Harper J and SenGupta S, Preimplantation genetic diagnosis for myotonic dystrophy type 1: detection of crossover between the gene and the linked marker APOC2. Prenatal Diagnosis, 27, 2007, 111-116.

[25]. Skrzypczak-Zielinska M, Sulek-Piatkowska A, Mierzejewski M and Froster UG, New analysis method of myotonic dystrophy 1 based on quantitative fluorescent polymerase chain reaction. Genetic Testing and Molecular Biomarkers, 13, 2009, 651-655.

[26]. Orpana AK, Ho TH, Alagrund K, Ridanpaa M, Aitommaki K and Stenman J, Novel Heat Pulse Extension-PCR based method for detection of large CTG-repeat expansion in myotonic dystrophy type 1. The Journal of Molecular Diagnostics, 15, 2012, 1-6.

[27]. Sermon K, Lissens W, Joris H, Seneca S, Desmyttere S, Devroey P, Steirteghem AV and Liebaers I , Clinical application of preimplantation diagnosis for myotonic dystrophy. Prenatal Diagnosis, 17, 1997, 925-932.

[28]. Warner JP, Barron LH, Goudie D, Kelly K, Dow D, Fitzpatrick DR and Brock DJH, A general method for the detection of large CAG repeat expansion by fluorescent PCR and repeat primed PCR. Journal of Medical Genetics, 33, 1996, 1022-1026.

[29]. Musova Z, Mazanec R, Krepelova A, Ehler E, Vales J, Jaklova R, Prochazka T, Koukal P, Marikova T, Kraus J et al., Highly unstable sequence interruptions of the CTG repeat in the myotonic dystrophy gene. American Journal of Human Genetics, 149A, 2009, 1365-1374.

[30]. Braida C, Stefanatos RK, Adam B, Mahajan N, Smeets HJ, Niel F, Goizet C, Arveiler B, Koenig M, Lagier-Tourenne C et al., Variant CCG and GGC repeats within the CTG expansion dramatically modify mutational dynamics and likely contribute toward unusual symptoms in some myotonic dystrophy type 1 patients. Human Molecular Genetics, 19, 2010, 1399-1412.

[31]. Radvansky J, Resko P, Surovy M, Minarik G, Ficek A and Kadasi L, High-resolution melting analysis for genotyping of the myotonic dystrophy type 1 associated Alu insertion/deletion polymorphism. Analytical Biochemistry, 398, 2010, 126-128.

[32]. Radvansky J and Kadasi L, The expanding world of myotonic dystrophies:How can they be detected. Genetic Testing and Molecular Biomarkers, 14, 2010, 733-741.

[33]. Piyamongkol W, Harper JC, Sherlock JK, Doshi A, Serhal PF, Delhanty JDA and Wells D, A successful strategy for preimplantation genetic diagnosis of myotonic dystrophy using multiplex PCR. Prenatal Diagnosis, 21, 2001 223-232.

[34]. Liquori CL, Ricker K, Moseley ML, Jacobsen JF, Kress W, Naylor SL, Day JW and Ranum LP, Myotonic dystrophy type 2 caused by a CCTG expansion in intron 1 of ZNF9. Science, 293, 2001, 864-867.

[35]. Bonifazi E, Gullotta F, Vallo L, Iraci R, Nardone AM, Brunetti E, Botta A and Novelli G, Use of RNA fluorescence in situ hybridization in the prenatal molecular diagnosis of myotonic dystrophy type 1. Clinical Chemistry, 52, 2006, 319-322.

[36]. Goldman A, Ramsay M and Jenkins T, Absence of myotonic dystrophy in southern african negroids is associated with a significantly lower number of CTG trinucleotide repeats. Journal of Medical Genetics, 31, 1994, 37-40.

[37]. Hojo K, Yamagata H, Moji H, Fujita T, Miki T, Fujimura M and Kidoguchi K (1995) Congenital myotonic dystrophy: molecular diagnosis and clinical study. American Journal of Perinatology, 12, 1995,195-200.

[38]. Guida M, Marger RS, Papp AC, Snyder PJ, Sedra MS, Kissel JT, Mendell JR and Prior TW, A molecular protocol for diagnosing myotonic dystrophy. Clinical Chemistry, 41, 1995,69-72.

[39]. Meiner A, Wolf C, Carey N, Okitsu A, Johnson K, Shelbourne P, Kunath B, Sauermann W, Thiele H, Kupferling P et al., Direct molecular analysis of myotonic dystrophy in the german population: important considerations in genetic counselling. Journal of Medical Genetics, 32, 1995, 645-649.

[40]. Nanba E, Ito T, Kadowaki K, Makio A, Nakagawa M, Yamamoto T, Yuasa I and Takeshita K, Prenatal diagnosis of congenital myotonic dystrophy in two Japanese families: direct mutation analysis by a non-radioisotope PCR method and haplotype analysis with flanking DNA markers. Brain and Development, 18, 1995, 122-126.

[41]. Sermon K, Vos AD, Van de Valde H, Seneca S, Lissens W, Joris H, Vandervorst M, Steirteghem AV and Liebaers I, Fluorescent PCR and automated fragment analysis for the clinical application of preimplantation genetic diagnosis of myotonic dystrophy (Steinert's disease). Molecular Human Reproduction, 4, 1998, 791-796.

[42]. Magnana JJ, Cortes-Reynosa P, Escobar-Cedillo R, Gomez R, Leyva-Garcia M and Cisneros B, Distribution of CTG repeats at the DMPK gene in myotonic dystrophy patients and healthy individuals from Mexican population. Molecular Human Reproduction, $38,2010,1341-1346$.

[43]. Hamzi K, Bellayou H, Slassi I and Nadifi S, A rapid polymerase chain reaction-based test for Steinert's disease. Neurology India, $58,2010,99-102$.

[44]. Radvansky J, Ficek A, Minarik G, Palffy R and Kadasi L, Effect of unexpected sequence interruptions to conventional PCR and repeat primed PCR in myotonic dystrophy type 1 testing. Diagnostic Molecular Pathology, 20, 2011, 48-51. 
Myotonic Dystrophy Type 1 Diagnostics: A Changing Trend

Appendix: Summary of the various PCR based techniques with conditions

\begin{tabular}{|c|c|c|c|c|}
\hline \multirow{2}{*}{$\begin{array}{l}\text { Refere } \\
\text { nces }\end{array}$} & \multicolumn{4}{|c|}{ PCR Conditions } \\
\hline & Primers & Master Mix & $\begin{array}{l}\text { Cycling } \\
\text { temperatur } \\
\text { e }\end{array}$ & Comments \\
\hline \multirow[t]{3}{*}{$\begin{array}{l}\text { Brook } \\
\text { et al. } \\
(1992)\end{array}$} & $\begin{array}{l}\text { 96forward:(GGTGCGTGGA } \\
\text { GGATGGAACACGGAC) } \\
\text { 103reverse:(CCAGTTCACA } \\
\text { ACCGCT CCGAGCGTG) }\end{array}$ & \multirow{3}{*}{ 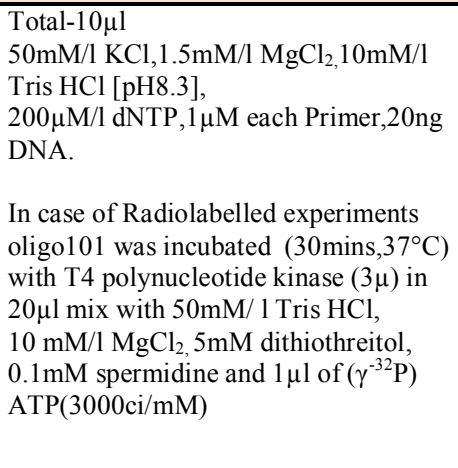 } & \multirow{3}{*}{$\begin{array}{l}94^{\circ} \mathrm{C} \times 3 \mathrm{~min} \\
35 \mathrm{cycles}:[ \\
94^{\circ} \mathrm{C} \times 10 \mathrm{sec}, \\
62^{\circ} \mathrm{C} \times 30 \mathrm{sec}, \\
72^{\circ} \mathrm{C} \times 30 \mathrm{sec} \\
] \\
72^{\circ} \mathrm{C} \times 5 \mathrm{~min}\end{array}$} & \multirow[t]{3}{*}{$\begin{array}{l}\text { Flanking PCR was } \\
\text { performed on patient } \\
\text { samples using three sets } \\
\text { of primers with primer } \\
\text { combination } 101 \text { and } 102 \\
\text { giving the best results }\end{array}$} \\
\hline & $\begin{array}{l}\text { 98reverse: } \\
\text { (GCGTGCGAGTGGACTAA } \\
\text { CAACAGCTG) } \\
\text { 100forward:(CACGCTCGGA } \\
\text { GCGGTTGTGAACTGG) }\end{array}$ & & & \\
\hline & $\begin{array}{l}101 \text { forward:(CTTCCCAGGC } \\
\text { CTGCAGTTTGCCCATC) } \\
\text { 102reverse:(GAACGGGGCT } \\
\text { CGAAGGGTCCTTGTAGC) }\end{array}$ & & & \\
\hline $\begin{array}{l}\text { Goldma } \\
\text { n et al. } \\
(1994)[ \\
36]\end{array}$ & $\begin{array}{l}\text { Used Primer101 and } 102 \\
\text { (Brook et al. ,1992) }\end{array}$ & 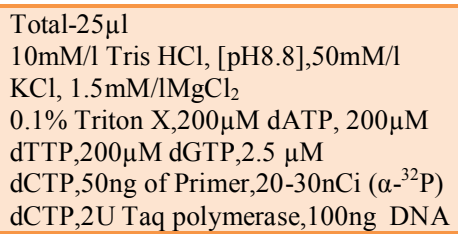 & $\begin{array}{l}35 \text { cycles: } \\
94^{\circ} \mathrm{C} \times 1 \mathrm{~min} \\
66^{\circ} \mathrm{C} \times 1 \mathrm{~min} \\
\left.72^{\circ} \mathrm{C} \times 1 \mathrm{~min}\right]\end{array}$ & $\begin{array}{l}\text { A flanking PCR was } \\
\text { performed on } 210 \\
\text { unrelated patients to } \\
\text { determine the size and } \\
\text { distribution of CTG } \\
\text { repeats }\end{array}$ \\
\hline $\begin{array}{l}\text { Hojo et } \\
\text { al. } \\
(1995)[ \\
37]\end{array}$ & $\begin{array}{l}\text { Used Primer101 and } 102 \\
\text { (Brook et al. ,1992) }\end{array}$ & $\begin{array}{l}\text { Total-25 } \mu \mathrm{l} \\
200 \mu \mathrm{M} / 1 \mathrm{dATP}, 200 \mu \mathrm{M} / 1 \\
\mathrm{dCTP}, 200 \mu \mathrm{M} / 1 \mathrm{dGTP}, 200 \mu \mathrm{M} / 1 \\
\text { dTTP,50pM primers, } 1 \mathrm{U} \text { Taq } \\
\text { polymerase, } \\
\text { 20ng DNA }\end{array}$ & $\begin{array}{l}94^{\circ} \mathrm{C} \times 3 \mathrm{~min} \\
35 \text { cycles: } \\
94^{\circ} \mathrm{C} \times 1.5 \mathrm{mi} \\
\mathrm{n}, \\
62^{\circ} \mathrm{C} \times 1 \mathrm{~min}, \\
\left.72^{\circ} \mathrm{C} \times 2 \mathrm{~min}\right] \\
72^{\circ} \mathrm{C} \times 5 \mathrm{~min} \\
4^{\circ} \mathrm{C} \text { forever }\end{array}$ & $\begin{array}{l}\text { Flanking PCR was } \\
\text { performed coupled with } \\
\text { Southern Blot to show } \\
\text { that DNA analysis is a } \\
\text { useful tool in prenatal } \\
\text { diagnosis }\end{array}$ \\
\hline $\begin{array}{l}\text { Guida } \\
\text { et al. } \\
(1995)[ \\
38]\end{array}$ & $\begin{array}{l}\text { Forward Primer : } \\
\left(5^{\prime}-\text { GCTCG AAGGGTCCTT }\right. \\
\text { GTAGCC-3') } \\
\text { Reverse Primer: } \\
\text { (5'-GGGGG } \\
\text { TGCGTGGAGGATGGAA- } \\
\left.3^{\prime}\right)\end{array}$ & $\begin{array}{l}\text { Total-50 } \mu 1 \\
3 \mathrm{mM} / 1 \mathrm{MgCl}, 67 \mathrm{mM} / 1 \text { Tris } \mathrm{HCl} \\
\text { [pH8.3],16.6mM/1 ammonium } \\
\text { sulphate, } 6.7 \mu \mathrm{M} \text { EDTA,10mM/1 } \\
\text { 2-mercaptoethanol, } 50 \mathrm{mg} / 1 \mathrm{BSA}, 100 \mathrm{~g} / 1 \\
\text { DMSO, } \\
300 \mathrm{nM} / 1 \mathrm{dNTP}, 3 \mathrm{U} \text { Taq } \\
\text { polymerase,150ng Primers, } \\
\sim 1 \mu \mathrm{g} \text { DNA }\end{array}$ & $\begin{array}{l}95^{\circ} \mathrm{C} \times 5 \mathrm{~min} \\
10 \text { cycles: } \\
95^{\circ} \mathrm{C} \times 1 \mathrm{~min}, \\
68^{\circ} \mathrm{C} \times 1 \mathrm{~min}, \\
20 \mathrm{cycles} \text { : } \\
62^{\circ} \mathrm{C} \times 2 \mathrm{~min}, \\
\left.72^{\circ} \mathrm{C} \times 5 \mathrm{~min}\right] \\
72^{\circ} \mathrm{C} \times 10 \mathrm{mi} \\
\mathrm{n}\end{array}$ & $\begin{array}{l}\text { The reverse primer used } \\
\text { is as per Mahadevan et } \\
\text { al(1992) and the forward } \\
\text { is primer is designed A } \\
\text { molecular protocol was } \\
\text { developed using flanking } \\
\text { PCR for the analysis of } \\
\text { normal patients followed } \\
\text { by the Southern Blot for } \\
\text { larger repeat size. }\end{array}$ \\
\hline $\begin{array}{l}\text { Meiner } \\
\text { et al. } \\
(1995)[ \\
39]\end{array}$ & $\begin{array}{l}\text { Used Primer101 and } 102 \\
\text { (Brook et al. ,1992) }\end{array}$ & $\begin{array}{l}\text { Total- } 50 \mu 1 \\
2 \mathrm{mM} / 1 \mathrm{MgCl}_{2}, 67 \mathrm{mM} / 1 \text { Tris } \mathrm{HCl} \\
{[\mathrm{pH} 8.8], 16.6 \mathrm{mM} / 1 \text { ammonium }} \\
\text { sulphate, } 6.7 \mu \mathrm{M} \text { EDTA,10mM/1 beta- } \\
\text { mercaptoethanol,200 } \mu \mathrm{M} / 1 \mathrm{dNTP}, 1 \mathrm{U} \\
\text { Taq polymerase, } \\
\text { 50pM Primers,200ng DNA }\end{array}$ & $\begin{array}{l}94^{\circ} \mathrm{C} \times 5 \mathrm{~min} \\
30 \mathrm{cycles}:[ \\
95^{\circ} \mathrm{C} \times 90 \mathrm{sec} \\
60^{\circ} \mathrm{C} \times 90 \mathrm{sec} \\
\left.72^{\circ} \mathrm{C} \times 3 \mathrm{~min}\right] \\
72^{\circ} \mathrm{C} \times 7 \mathrm{~min}\end{array}$ & $\begin{array}{l}\text { Direct method of analysis } \\
\text { is used to analyse patients } \\
\text { of German population } \\
\text { using flanking PCR. }\end{array}$ \\
\hline $\begin{array}{l}\text { Cheng } \\
\text { et al. } \\
\text { (1996) }\end{array}$ & $\begin{array}{l}\text { DMK9003 forward:(5`- } \\
\text { CACAGGCTGAAGTGG } \\
\text { CAGTTCCA -3') } \\
\text { DMK11111 reverse: }\left(5^{\prime}-\right. \\
\text { TGTCGGGGTCTCAGT } \\
\text { GCATCCA-3') }\end{array}$ & $\begin{array}{l}\text { Total- } 50 \mu \mathrm{l} \\
1 \mathrm{XPCR} \\
\text { buffer, } 1.5 \mathrm{mM} / 1 \mathrm{Mg}(\mathrm{OAc})_{2}, 10 \mathrm{mM} / 1 \text { Tris } \\
\mathrm{HCl} \text {, } \\
50 \mathrm{mM} / 1 \mathrm{EDT} \mathrm{A}, 0.2 \mathrm{mM} \text { dATP, } 0.2 \mathrm{mM} \\
\mathrm{dCTP} \text {, } \\
0.2 \mathrm{mM} \text { dGTP, } 0.2 \mathrm{mM} \mathrm{dTTP}, 7 \text {-deaza } \\
\text { dGTP } \\
1 \mathrm{U} \text { Taq polymerase,15-50ng DNA }\end{array}$ & $\begin{array}{l}95^{\circ} \mathrm{C} \times 15 \mathrm{sec} \\
\mathrm{Mg}(\mathrm{OAc})_{2} \\
\text { or } \\
94^{\circ} \mathrm{C} \times 45 \mathrm{sec}, \\
24 \text { or } 33 \\
\text { cycles: } \\
{\left[95^{\circ} \mathrm{C} \times(10-\right.} \\
12) \mathrm{sec}, \\
66^{\circ} \mathrm{C} \times 6 \mathrm{~min}, \\
\left.67^{\circ} \mathrm{C} \times 6 \mathrm{~min}\right] \\
68^{\circ} \mathrm{C} \times(5- \\
10) \mathrm{min}\end{array}$ & $\begin{array}{l}\text { In case of hot start PCR } \\
\text { with "bulk" DNA } \\
\text { reactions } \mathrm{Mg}(\mathrm{OAc})_{2,} \text {, was } \\
\text { held till the temperature } \\
\text { reaches } 78^{\circ} \mathrm{C} \text { and for low } \\
\text { copy reactions Ampli } \\
\text { WAX }{ }^{\mathrm{TM}} \text { was used. } \\
\text { This method made use of } \\
\text { flanking PCR to analyze } \\
\text { large CTG repeats in the } \\
\text { case of Myotonic } \\
\text { Dystrophy hence making } \\
\text { the diagnosis simpler. }\end{array}$ \\
\hline $\begin{array}{l}\text { Nanba } \\
\text { et al. } \\
(1996)[ \\
40]\end{array}$ & $\begin{array}{l}\text { Used Primer101 and } 102 \\
\text { (Brook et al. ,1992) }\end{array}$ & $\begin{array}{l}\text { Total- } 20 \mu 1 \\
1.5 \mathrm{mM} \mathrm{MgCl}, 50 \mathrm{mM} \mathrm{KCl}, 10 \mathrm{mM} \text { Tris } \\
\mathrm{HCl} \text {, } \\
10 \% \text { DMSO,200mM dNTP,1U Taq } \\
\text { polymerase, } \\
\text { 20pM Primers,250ng DNA }\end{array}$ & $\begin{array}{l}94^{\circ} \mathrm{C} \times 3 \mathrm{~min} \\
30 \text { cycles: } \\
94^{\circ} \mathrm{C} \times 1 \mathrm{~min} \\
65^{\circ} \mathrm{C} \times 1 \mathrm{~min} \\
\left.72^{\circ} \mathrm{C} \times 1 \mathrm{~min}\right]\end{array}$ & $\begin{array}{l}\text { The prenatal diagnosis } \\
\text { was performed using } \\
\text { Non-radioisotopic PCR } \\
\text { method of analysis. }\end{array}$ \\
\hline
\end{tabular}




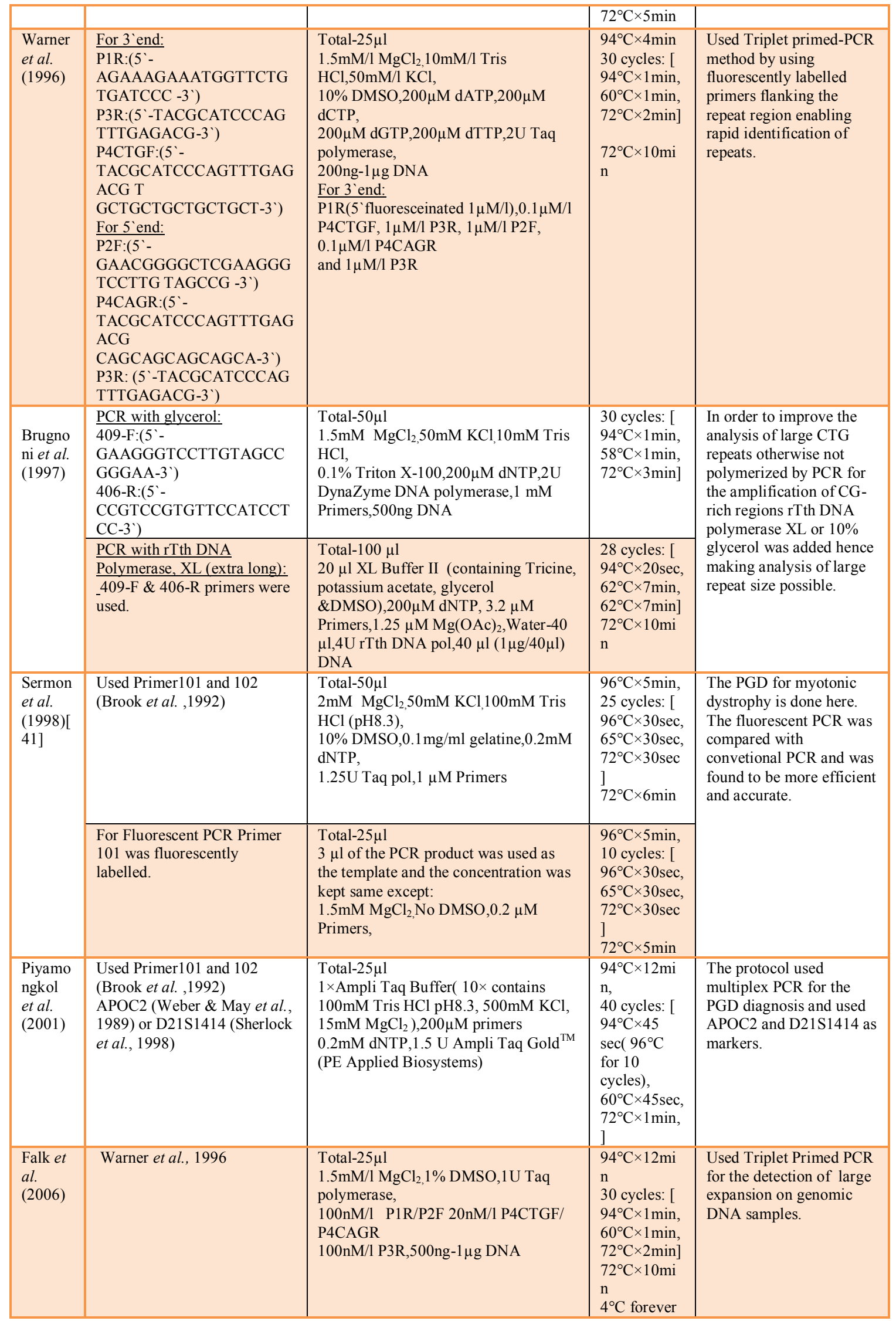




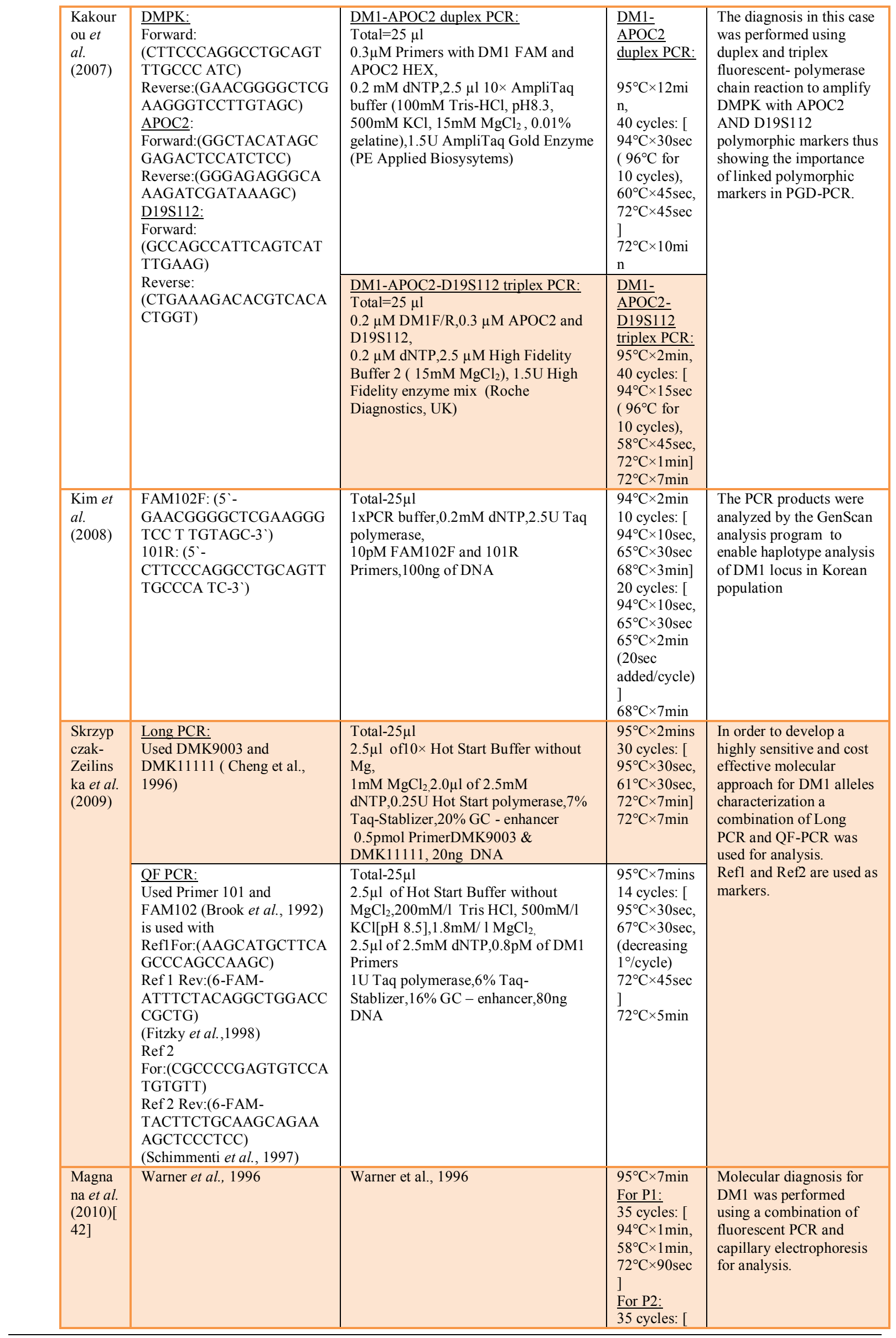




\begin{tabular}{|c|c|c|c|c|}
\hline & & & $\begin{array}{l}94^{\circ} \mathrm{C} \times 1 \mathrm{~min}, \\
59^{\circ} \mathrm{C} \times 1 \mathrm{~min}, \\
72^{\circ} \mathrm{C} \times 120 \mathrm{se} \\
\mathrm{c}] \\
5 \mathrm{~min} \text { in ice }\end{array}$ & \\
\hline $\begin{array}{l}\text { Hamzi } \\
\text { et al. } \\
(2010)[ \\
43]\end{array}$ & $\begin{array}{l}5^{`}- \\
\text { GAAGGGTCCTTCTAGCC } \\
\text { GGGAA-3`} \\
5^{`}- \\
\text { CAGAGCAGGGCGTCATG } \\
\text { CAGC-3` }\end{array}$ & 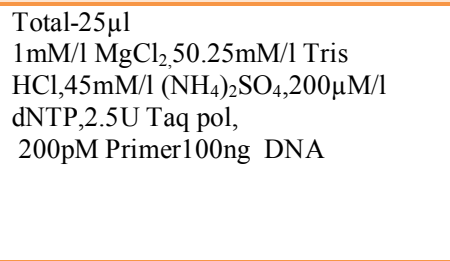 & $\begin{array}{l}95^{\circ} \mathrm{C} \times 10 \mathrm{mi} \\
\mathrm{n} \\
30 \text { cycles: } \\
94^{\circ} \mathrm{C} \times 1 \mathrm{~min}, \\
60^{\circ} \mathrm{C} \times 1.5 \mathrm{mi} \\
\mathrm{n}, \\
\left.72^{\circ} \mathrm{C} \times 2 \mathrm{~min}\right] \\
72^{\circ} \mathrm{C} \times 5 \mathrm{~min}\end{array}$ & $\begin{array}{l}\text { Used rapid PCR method } \\
\text { for initial screening of the } \\
\text { samples and the positive } \\
\text { samples can be confirmed } \\
\text { by TP-PCR and Southern } \\
\text { Blot. }\end{array}$ \\
\hline $\begin{array}{l}\text { Radvan } \\
\text { sky et } \\
\text { al. } \\
(2011)[ \\
44]\end{array}$ & $\begin{array}{l}\text { For forward end: } \\
\text { P1F:(5`- } \\
\text { GGGGCTCGAAGGGTCCT } \\
\text { TGT-3`) } \\
\text { P4CAGR: (5`- } \\
\text { AGCGGATAACAATTTCA } \\
\text { CACA } \\
\text { GGACAGCAGCAGCAGCA } \\
\text { GCAG-3') } \\
\text { P3:(5`AGCGGATAACAATT } \\
\text { TCACACAGGA-3') } \\
\text { P2R:(5'- } \\
\text { GGGGCTCGAAGGGTCCT } \\
\text { TGT-3`) } \\
\text { P4CTGF:(AGCGGATAACA } \\
\text { ATTTCACACAGGATGCTG } \\
\text { CTGCTGCTGCTGCTG-3') } \\
\text { P3: (5`- } \\
\text { AGCGGATAACAATTTCA } \\
\text { CACAGGA-3') }\end{array}$ & $\begin{array}{l}\text { Total-10 } \mu 1 \\
1 \times \text { PCR buffer, } 1.5 \mathrm{mM} / 1 \mathrm{MgCl}_{2}, 1 \mathrm{M} \\
\text { Betaine, } 150 \mu \mathrm{M} / 1 \mathrm{dNTP}, 0.25 \mathrm{U} \text { Taq } \\
\text { polymerase,2pM P1F, } \\
\text { 0.5pmolP4CAGF, P4CTGF, } 1.5 \mathrm{pM} \\
\text { P3,300ng DNA }\end{array}$ & $\begin{array}{l}95^{\circ} \mathrm{C} \times 5 \mathrm{~min} \\
34 \text { cycles: } \\
94^{\circ} \mathrm{C} \times 1 \mathrm{~min}, \\
65^{\circ} \mathrm{C} \times 1 \mathrm{~min}, \\
\left.72^{\circ} \mathrm{C} \times 2 \mathrm{~min}\right]\end{array}$ & $\begin{array}{l}\text { Used combination of } \\
\text { bidirectionally labelled } \\
\text { conventional PCR with } \\
\text { TP-PCR in both } \\
\text { directions for increasing } \\
\text { reliability and accuracy of } \\
\text { TP-PCR based assay to } \\
\text { analyze genomic DNA. }\end{array}$ \\
\hline \multirow[t]{2}{*}{$\begin{array}{l}\text { Orpana } \\
\text { et al. } \\
(2012)\end{array}$} & $\begin{array}{l}\text { FAM-DM3107F:(5`- } \\
\text { CTTCCCAGGCCTGCAGT } \\
\text { TTGCCCAATCC-3`) } \\
\text { DM3108R:(5`- } \\
\text { GAACGGGGCTCGAAGGG } \\
\text { TCC T TGTAGCC-3`) }\end{array}$ & $\begin{array}{l}\text { Total-50 } \mu 1 \\
1 \mathrm{xPCR} \text { buffer, } 160 \mu \mathrm{M} / \mathrm{L} \mathrm{dNTP}, 0.8 \mathrm{U} \\
\text { Taq polymerase,20pMFAM-DM3107 } \\
\text { and DM3108, } \\
\text { 20ng of DNA }\end{array}$ & $\begin{array}{l}94^{\circ} \mathrm{C} \times 10 \mathrm{mi} \\
\mathrm{n} \\
20 \text { cycles: [ } \\
95^{\circ} \mathrm{C} \times 1 \mathrm{~min} \text {, } \\
68^{\circ} \mathrm{C} \times 1 \mathrm{~min} \\
(\text { decreasing } \\
\text { to } 60^{\circ} \mathrm{C} \text { at }- \\
\left.0.4^{\circ} \mathrm{C} / \text { cycle }\right) \\
] \\
72^{\circ} \mathrm{C} \times 3 \mathrm{~min} \\
16 \text { cycles: [ } \\
95^{\circ} \mathrm{C} \times 1 \mathrm{~min} \text {, } \\
60^{\circ} \mathrm{C} \times 1 \mathrm{~min} \\
\text { Ramp to } \\
72^{\circ} \mathrm{C} \times 3 \mathrm{mins} \\
]^{\circ} \\
72^{\circ} \mathrm{C} \times 10 \mathrm{mi} \\
\mathrm{n}\end{array}$ & \multirow[t]{2}{*}{$\begin{array}{l}\text { In case of Heat pulse } \\
\text { extension PCR a } \\
\text { continuously shifting } \\
\text { extension temperature } \\
\text { allows extension of large } \\
\text { CTG repeats. }\end{array}$} \\
\hline & $\begin{array}{l}\text { DMKF:( } 5^{`}- \\
\text { GCCAGTTCACAACCGCTC } \\
\text { CGAG CGTGGGTC-3`) } \\
\text { DMKR:(5`- } \\
\text { ACGCTCCCCAGAGCAGG } \\
\text { GCGTCA TGC-3') }\end{array}$ & $\begin{array}{l}\text { Total- } 40 \mu \mathrm{l} \\
1 \mathrm{xPCR} \text { buffer, } 200 \mu \mathrm{M} / \mathrm{L} \mathrm{dNTP}, 1.33 \mathrm{U} \\
\text { Taq polymerase,100pM DMKf and } \\
\text { DMKr,2.25mM/L Betaine and 40ng of } \\
\text { DNA }\end{array}$ & $\begin{array}{l}94^{\circ} \mathrm{C} \times 7 \mathrm{~min} \\
40 \mathrm{cycles}:[ \\
95^{\circ} \mathrm{C} \times 45 \mathrm{sec} \\
98^{\circ} \mathrm{C} \times 10 \mathrm{sec} \\
68^{\circ} \mathrm{C} \times 30 \mathrm{sec} \\
\text { Ramp to } \\
76^{\circ} \mathrm{C} \\
(30 \% \text { ramp } \\
\text { rate) } \\
21 \times \text { Ramp to } \\
83^{\circ} \mathrm{C}(30 \%) \\
\left.76^{\circ} \mathrm{C} \times 2 \mathrm{sec}\right]\end{array}$ & \\
\hline
\end{tabular}

[Only the methods giving complete information of the conditions are listed above] 